\title{
The Antecedents of Culture-Based Tourism Destination Sustainability in Indonesia
}

\author{
M Elfan Kaukab ${ }^{1 *}$, Atinia Hidayah ${ }^{2}$, Christina $^{2}$ \\ ${ }^{1}$ Faculty of Economics, Universitas Sains Al-Quran Jawa Tengah, Wonosobo, Indonesia \\ ${ }^{2}$ Faculty of Language and Literature, Universitas Sains Al-Quran Jawa Tengah, Wonosobo, Indonesia \\ *Corresponding author. Email: elfan@unsiq.ac.id
}

\begin{abstract}
Awareness of tourism destination sustainability is important to protect the destination from damage and overexploitation. Studies on tourism destination sustainability are still in the early stages. Scholars have just developed the indicators and instruments that will be used to measure the destination sustainability. The purpose of this paper is to identify factors that influence culture-based tourism destination sustainability. We present regression analysis of potential antecedents of culture-based tourism destination of 5 cultural destinations in Central Java involving 200 local people. The result suggests that tourist guides' performance has the strongest effect on culture-based destination sustainability. It is complemented with resources performance and innovation. This indicates the importance of tourist guides' training and orientation in building tourists' awareness.
\end{abstract}

Keywords: tourist destination sustainability, tourism resources, destination innovation, tour guides'

performance, cultural destination

\section{INTRODUCTION}

The tourism condition in the past few years has increased the tension in the countries that should develop their sustainable destination, including the culture-based destinations. This is because now the focus of tourism is sustainable destinations [1]-[3]. Considering this trend, the researchers modify tourism variables to comply with the sustainability aspect [4], [5]. We specifically begin to develop the concept of tourism destination sustainability [6]-[12]. Tourism destination sustainability is defined as "how vast the economic, social, and environmental impact of tourism to a destination is" [13].

As attentions to the sustainability of tourism destinations are given, it is important that the administrators consider the antecedents. Understanding the antecedents allows them to determine the right ways in encouraging tourism destination sustainability. Sustainability should support the efforts to increase local society's welfare and preserve the environment.

However, the currently available research's focus is on natural destinations instead of cultural destinations [14][16]. Only a small number of ongoing research aims at cultural destinations although these destinations strongly relate to local's social welfare and identity.

Resource-based view (RBV) has made resources, which are defined as "all assets, capabilities, organization process, company attributes, information, knowledge, and so forth that are controlled by companies that enable them to formulate and implement strategies to increase their efficiency and effectivity," play a role as an important antecedent of destination's sustainability [3], [11], [18]. Specifically, a rare, valuable, inimitable, and irreplaceable resource can act as a booster for the sustainable competitiveness of a destination [19].

Besides, a modern competitive climate encourages companies to come up with new ideas to prevent tourists' boredom over conservative cultural destinations. Some previous studies [3], [20] give strong evidence that innovation is important in increasing destinations' sustainability. Therefore, the innovation factor likely determines the sustainability of culture-based destinations. For the same reason, human resource is also important and need to be treated in a special place as an inimitable and irreplaceable. Tour guides are important human resources in cultural destinations. Human capital theory [21] states that human resources, including tour guides, determine the destinations' success. Therefore, we propose that the tour guide is an important antecedent in culture-based destinations' sustainability. Previous studies have revealed that tour guides' performance is an antecedent for tourists' satisfaction, destinations' loyalty, and memorable tourism experiences. They, in turn, uplift the destinations' competitiveness and sustainability [22], [23]. The same thing applies to culture-based tourism destinations' sustainability.

We try to fill in the gap in the literature of tourism destinations' sustainability by showing how destinations' managers achieve culture-based destinations' sustainability. They do it by optimizing resources, innovation, and tour guides' performance. We contribute to the literature of tourism destination sustainability especially the culture-based tourism destination - by examining its three antecedent variables using the resourcebased view theoretical framework [17]. In order to be complementary to the existing literature, this study will elaborate on the reason why resources, innovation, and tour guides' performance are factors specifically aimed at 
increasing culture-based tourism destination's sustainability. We hypothesize that resources, innovation, and tour guides' performance will have significant effects on the sustainability of culture-based tourist destinations. Moreover, this research contributes to the understanding of resources forms that are vital to the sustainability of culturebased destinations.

The resource-based view (RBV) claims that sustainable competitive advantage derives from the possessed resources and the capability to manage those resources and change them into excellent business strategies [17]. RBV is commonly used as a theoretical basis in studies of sustainable tourism [24]-[26]. It is a grand theory. Some smaller theories have specifically excelled certain types of resources. Resources exchange theory [27] describes certain types of resources excel in boosting motivation for social shift based on particularism and concreteness. Knowledgebased vies (KBV) considers knowledge and innovation as the primary resources [28]. Meanwhile, the human capital theory features human resources as primary resources.

Generally, resources directly connect to their usefulness context. Thus, resources aimed at increasing tourists' visit will benefit the visit. To create a destination's sustainability, resources directly aimed at increasing sustainability, such as green innovation, environmentally friendly technology, and energy-saving promotion, should be used [28]. Nevertheless, for culture-based destinations, we believe that a direct connection to the destination's sustainability is also formed. There are three reasons for this. First, culturedestinations offer authenticity and therefore advancing preservation [31]. This leads to maintaining originality, including the local customs. It means that culture-based tourist destinations empower the local community. Local community empowerment is a form of sustainable tourism. As a consequence, resources will tie to the local community and form a direct connection. Second, culture-based destinations automatically aim at conservation, in this case, cultural conservation [32]. It is far from cultural degradation and will point to social life as well as cultural-resources utilization. It also aims at sustainable cultural-tourism building so long as it is supported by good cultural livelihood and resources [32]. This includes resources elements of sustainable cultural tourism. Third, culturebased destinations are tightly bound to creative tourism, which in turn stands on authenticity provided by local culture [33]. This will effectively be achieved if the local community is empowered because they are the ones who understand truly the cultural values of the destination. Any kinds of resources enable the local community and the surrounding environment to develop better. Thus, the destination is sustainable. Detailed elaboration of each theory and its connection to the culture-based tourist destinations are given in the following.

\subsection{Resources as a potential antecedent}

RBV lays a foundation to establish resources as potential antecedents of culture-based tourism destination's sustainability. Resources exchange theory [27] classifies resources based on solid theory. It states that human activities take place due to resources exchange. People call this exchange as a reward. The theory is relevant to present studies since the resources possessed by destinations can be seen as things traded for tourists to obtain intense visits with sustainability principles.

According to resources exchange theory, resources are grouped based on the particularism and concreteness dimensions [34]. The particular resources are harder to trade than the less particular resources. The concrete resources are easier to identify than abstract resources. Based on this consideration, Foa and Foa [27] formulize six types of resources different in particularism and concreteness. They are status, information, money, goods, service, and love. Status, love, and service are particular resources while information, money, and items are less particular. Status and information are abstract resources whilst service and goods are concrete. Love and money are placed in between abstract and concrete.

All of the resources' types can be argued as important in increasing culture-based tourist destination. Goods as concrete forms of destination are reflected in the destination's quality. Service is reflected in the quality of service provided for the tourists. Love can be found in the community's friendliness towards the tourists. Money is related to the budget of a destination's operation. Information relates to the knowledge possessed as an additional value of a culture-based destination. Status connects to the destination's image in international tourism. However, it is unclear if the resources can make the destination sustainable as in providing benefits for the poor and less fortunate people, empowering the local community, smoothening tourist visits, and eliminating discrimination in the society.

Resources exchange theory suggests a direct relationship between resources and culture-based tourism destination's attractiveness, but it does not guarantee the relationship between resources and sustainability. This is because a destination's attractiveness connects to the relationship between the destination's manager and the tourists. It is different from the culture-based destination in which the community and culture are among the important assets to attract tourists [32]. Resources such as budget, information, destination's quality, destination's image, service quality, and friendliness should be in line with and affect the sustainability of a culture-based destination.

H1: Resources will significantly affect the sustainability of the culture-based destination

\subsection{Innovation as a potential antecedent}

Researchers have analyzed innovation and its effect on a destination's sustainability [35], [36]. Experts agree that innovation is an important variable in a destination's sustainability [37]-[40]. It also is a prominent variable of the knowledge-based view (KBV) [41]. KBV states that knowledge creation and application are the key activities behind superior performance [41].

Innovation is also a broad concept. It has been defined as "a multi-stage process in which an organization transforms ideas into products, services, or new or better processes to encourage itself to move forward, compete, and distinguish it successfully in the market" [42]. Innovation can be in a 
specific feature in a certain context [43]. Innovation that is not relevant in a certain situation might turn into unnecessary waste. Relevant innovation leads to the main aspects of service to tourists. Generally, innovation in the organization method, marketing, service, product, infrastructure, and structure might play a major role in increasing visits to a destination.

A question arises later on whether these innovations can improve the sustainability of a destination such as increasing the benefit for the local society, boosting social and aid programs for the less fortunate, and minimize the impact on society. In a common destination, this might be unrelated. But, in the context of a culture-based destination, innovation has a major role in maintaining sustainability. The innovations can be carried out by empowering the local community in marketing, infrastructure maintenance, and consultation on handicraft innovation. Thus, we suspect that high innovations in culture-based destinations will create sustainability of the destinations.

H2: Innovations will significantly affect the sustainability of culture-based destinations

\subsection{Tour guides' performance as a potential antecedent}

Tour guides have an important role as a travel-experience creator [23]. A study by Nguyen [22] revealed that tour guides can generate tourist satisfaction and destination loyalty. One of the advantages of culture-based destination's tour guides is the big role they play in encouraging tourist satisfaction in cultural tours [44] and connecting tourists' needs to the service provided by the local community [45].

The performance of culture-based tour guides can be measured from several things such as the ability in introducing the local custom and norm, the responsibility in ensuring tourists' safety, the provision of special service, and the information sharing on local history and culture. At a glance, those things seem to be unrelated to destination sustainability. However, as it has been argued earlier, culture-based destinations have the specific characteristics that can help them in connecting tour guides' performance to sustainability. As an example, tour guides can build tourists' appreciation towards the local community that makes them friendlier ignoring society's social strata. Tourists can also socially contribute to the local community by knowing the history and the value of the destination. Relying on their knowledge of local history, tourists will make efforts to minimize the impact they create on the environment for maintaining the destination's originality. Besides, interaction with the local people will help them intensively explore the local culture of the destination they visit. These cannot be found in non-culture-based destinations like in modern recreation centers or naturebased destinations. Therefore, we hypothesize:

H3: Tour guides' performance will have a positive and significant influence on culture-based destination sustainability.

\section{METHOD}

\subsection{Participants and procedures}

Our samples are local people who make a living around the five culture-based destinations in Central Java, Indonesia. The respondents of various occupations were asked to fill in the directly-distributed questionnaires. Forty questionnaires are distributed in each destination, yielding a total sample of 200 people.

\subsection{Measures}

a. Resources

The questionnaire demands answers about the condition of the resources in the destination using a six-item-scale developed from resources exchange theory [34]. The example items are among other "destination image in the international tourism" and "local people's friendliness towards the tourists." The responses are made based on the 5 -item Likert scale $(1=$ very bad; 5 $=$ very good)

b. Innovation

We asked the respondents to answer questions on innovation using company-level innovation scale by Hoskens et al [46] (five items). The question samples include "in the past three years, has the destination ever created a new marketing method or strategy effective in attracting tourists?" and "in the past three years, has the destination renovated the infrastructure to be better and more interesting?" The responses are made on a binary scale $(1=$ No, $2=$ Yes $)$.

c. Tour guides' performance

Observation of the local society has made it possible for tour guides' performance instruments to be filled by modifying the questionnaire provided by Caber et al [47], which consists of nine items. The item samples include "tour guides in this destination generally recommend attending special events" and "tour guides in this destination commonly act as translators for the tourists in communicating with the local people." The responses are made using a 5-item Likert scale $(1=$ strongly agree; $5=$ strongly disagree).

d. Sustainability of tourism destination

Local community measure the sustainability of tourism destination using destination sustainability questionnaire developed by Mathew and Sreejesh [1] comprises of 22 items (the dimension includes economic sustainability, social sustainability, culture sustainability, and environmental sustainability). The item examples include "income gained by the local community from a stable destination from time to time" and "this destination develops the local community." The responses are made using a 5 -item Likert scale $(1=$ strongly disagree, $5=$ strongly agree).

e. Social desirability To avoid social desirability bias, which is the respondent answering the question in a seemingly acceptable way [48], we employed social desirability as 
a control variable. The questionnaire measuring desirability bias uses nine-item Arnaud's questionnaire [49]. The item examples include "I sometimes feel annoyed by people asking for my help" and "I sometimes feel annoyed when I can't reach my goal." The responses are made in a binary scale $(1=$ True, $2=$ False).

\subsection{Analytical approach}

We employ linear regression to test our three hypotheses. Resources, innovation, tour guides' performance, and social desirability are the free variables in this research, while destination sustainability is the bound variable. ANOVA is run to examine the difference between destination, gender, age, education, and occupation in answering the research questions.

\section{RESULTS AND DISCUSSION}

Tables 1 and 2 display the reliability coefficient and descriptive statistics. As it is seen, the construct reliability of the three variables is accepted per Nunnally recommendation, namely the minimum reliability 0.70 [49]. Innovation reliability is 0.679 , which is still under the acceptable limit considering that innovation scale is a newly developed scale.

Table 1 Reliability Coefficients

\begin{tabular}{|lccc|}
\hline \multicolumn{1}{|c}{ Variables } & $\begin{array}{c}\text { Number of } \\
\text { Items }\end{array}$ & $\begin{array}{c}\text { Items } \\
\text { Dropped }\end{array}$ & Cronbach $\boldsymbol{\alpha}$ \\
\hline Resources & 6 & - & 0.887 \\
\hline Innovation & 5 & 3 & 0.679 \\
\hline Performance & 9 & - & 0.843 \\
\hline Sustainability & 22 & - & 0.963 \\
\hline
\end{tabular}

Table 2 Descriptive for The Major Variables

\begin{tabular}{|lcc|}
\hline \multicolumn{1}{|c|}{ Variables } & Mean & SD \\
\hline Resources & 4.22 & 0.46 \\
\hline Innovation & 1.71 & 0.39 \\
\hline Performance & 4.43 & 0.37 \\
\hline Sustainability & 4.04 & 0.50 \\
\hline
\end{tabular}

Table 3 shows the intercorrelation between variables. The observed correlation ranges from 0.184 to 0.476 , showing the absence of multicollinearity in the research data.

Table 3 Intercorrelations of the Major Variables

\begin{tabular}{|lllll|}
\hline \multicolumn{1}{|c}{ Variable } & \multicolumn{1}{c|}{ Resou } & Innov & Perform & Sustain \\
\hline Resource & 1.000 & & & \\
\hline Innovation & $0.216^{* *}$ & 1.000 & & \\
\hline Performance & $0.204^{* *}$ & $0.184^{*}$ & 1.000 & \\
\hline Sustainability & $0.304^{* * *}$ & $0.270^{* * *}$ & $0.476^{* * *}$ & 1.00 \\
\hline \multicolumn{5}{r}{ Note: ${ }^{*} \mathrm{p}<0.05 ; * \mathrm{p}<0.01 ; * * \mathrm{p}<0.001$} \\
\end{tabular}

Table 4 shows the respondents' profile. The majority of them are female (56.5 percent) and the largest age proportion is $31-40$ ( 35.5 percent) and $21-30$ (33.5 percent). Around 63.5 percent of the respondents are high school graduates.
Table 4 Demographic Results

\begin{tabular}{|ccccc|}
\hline No & Profile & Description & Respondents & Percentage \\
\hline \multirow{2}{*}{1} & Gender & Male & 86 & 43,0 \\
\cline { 3 - 5 } & & Female & 113 & 56.5 \\
\hline \multirow{2}{*}{2} & Age & $21-30$ & 67 & 33.5 \\
\cline { 3 - 5 } & & $31-40$ & 71 & 35.5 \\
\cline { 3 - 5 } & & $41-50$ & 52 & 26.0 \\
\cline { 3 - 5 } & Education & $\begin{array}{c}\text { Junior high } \\
\text { school }\end{array}$ & 62 & 4.5 \\
\cline { 3 - 5 } & & $\begin{array}{c}\text { Senior high } \\
\text { school }\end{array}$ & 127 & 31.0 \\
\cline { 3 - 5 } & & Diploma & 8 & 63.5 \\
\cline { 3 - 5 } & & Bachelor & 1 & 4.0 \\
\cline { 3 - 5 } & & & & 0.5 \\
\hline
\end{tabular}

The hypothesis is tested using regression analysis and the result is shown in Figure 1. The result shows that resources positively affect destination sustainability $(\beta=0.184, p$ $<0.01)$. These results indicate that concrete and abstract resources [34] also play an important role in the sustainability of cultural-based destinations, in line with resources exchange theory. Furthermore, this confirms that the resources in the Foa and Foa classifications [27] play a role in eliminating discrimination as well as other things that distinguish aspects of the sustainability of the destination with the performance of the destination in general. This finding is in line with a number of studies focusing on the aspect of resources [35] [37].

Similar effect is also displayed by innovation $(\beta=0.151, \mathrm{p}$ $<0.05$ ). The finding that innovation influences destination sustainability shows that the innovations made by destination are appropriate to the context [43]. This innovation is carried out by paying attention to local communities and the environment such as empowering local communities, as well as paying attention to more general matters such as infrastructure. Previous research also emphasized the importance of innovation in the sustainability of destinations [37] [40].

Tourist guides' performance has a positive connection to cultural destination sustainability $(\beta=0.407, \mathrm{p}<0.001)$. This shows that the behavior of tour guides has helped pay attention to aspects of sustainability. In addition, these results are in line with previous studies on the context of similar destinations in other countries [22], [44], [45].

The H1-H3 of this research are fully supported. It can be seen that tourist guides' performance is the most significant predictor in cultural destination sustainability. The 0.291 R2 value indicates that 29.1 percent of cultural destination sustainability variance can be elaborated by resources, innovation, and tourist guides' performance. This coefficient is low, indicating that there are many other factors influencing cultural destination sustainability.

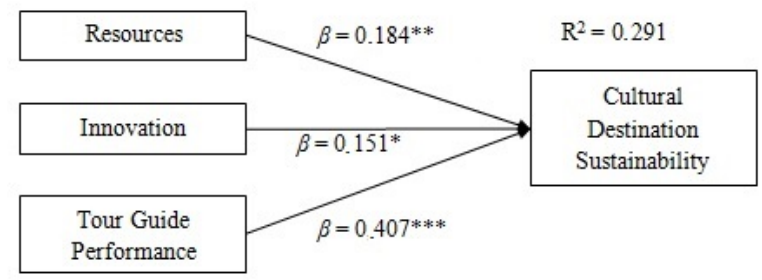

Figure 1 Results of the regression analysis 
Evidence From Piedmont, Italy," in Global Conference on Services Management, 2017, pp. 139-141.

[4] M. Cucculelli and G. Goffi, "Does sustainability enhance tourism destination competitiveness? Evidence from the Italian Destinations of Excellence," J. Clean. Prod., vol. 111, pp. 370-382, 2016.

[5] J. Soulard, W. Knollenberg, B. B. Boley, R. R. Perdue, and N. G. McGehee, "Social capital and destination strategic planning," Tour. Manag., vol. 69, pp. 189-200, 2018.

[6] A. Almeida-Santana and S. Moreno-Gil, "Understanding tourism loyalty: Horizontal vs destination loyalty," Tour. Manag., vol. 65, pp. 245 $255,2018$.

[7] Y. Coşar, A. Timur, and M. Kozak, "The influence of slow city in the context of sustainable destination marketing," in Marketing Places and Space, Vilamoura, Portugal: Emerald Group Publishing Ltd., 2015, pp. 209-220.

[8] Q. Jin, H. Hu, and P. Kavan, "Factors Influencing Perceived Crowding of Tourists and Sustainable Tourism Destination Management," Sustainability, vol. 8, no. 976, pp. 1-17, 2016

[9] M. Esparon, N. Stoeckl, M. Farr, and S. Larson, "The significance of environmental values for destination competitiveness and sustainable tourism strategy making: insights from Australia's Great Barrier Reef World Heritage Area," J. Sustain. Tour., vol. 23, no. 5, pp. 706-725, 2015.

[10] B. Bramwell, "Theoretical activity in sustainable tourism research,” Ann. Tour. Res., vol. 54, pp. 204$218,2015$.

[11] N. Čavlek, C. Cooper, V. Krajinović, L. Srnec, and K. Zaninović, "Destination Climate Adaptation," J. Hosp. Tour. Res., vol. 43, no. 2, pp. 314-322, 2019.

[12] L. Dwyer, V. Dragicevic, T. Armenski, T. Mihalic, and L. K. Cvelbar, "Achieving Destination Competitiveness: an Importance -Performance Analysis of Serbia," Curr. Issues Tour., vol. 19, no. 13, pp. 1309-1336, 2016.

[13] S. Cheuk, M. C. Lo, and A. Atang, "Rural Tourism Destination Performance in East Malaysia: Influencing Factors from the Communities' Perspective," J. Sustain. Dev., vol. 8, no. 3, p. 124, 2015.

[14] L. Su, S. (sam) Huang, and J. Pearce, "How does destination social responsibility contribute to environmentally responsible behaviour? A destination 
[26] I. Rihova, D. Buhalis, M. Moital, and M. Gouthro, "Conceptualising Customer-to-customer Value Cocreation in Tourism," Int. J. Tour. Res., vol. 17, no. 4, pp. 356-363, 2015.

"Stakeholders' Perspectives of Sustainable Tourism Development : A New Approach to Measuring Outcomes," J. Travel Res., vol. 55, no. 4, pp. 465-480, 2016.

[16] B. K. Miocic, M. Razovic, and T. Klarin, "Management of sustainable tourism destination through stakeholder cooperation," Management, vol. 21, no. 2, pp. 99-120, 2016.

[17] J. Barney, "Firm Resources and Sustained Competitive Advantage," J. Manage., vol. 17, no. 1, pp. 99-120, 1991.

[18] S. Grapentin and M. Ayikoru, "Destination Assessment and Certification : Challenges and Opportunities," Sustainability, vol. 11, no. 3691, pp. 124, 2019.

[19] P. Binder, “A network perspective on organizational learning research in tourism and hospitality: A systematic literature review," Int. J. Contemp. Hosp. Manag., 2019.

[20] C. Zhang, H. Xiao, D. Gursoy, and Y. Rao, “Tacit Knowledge Spill Over and Sustainability in Destination Development,” J. Sustain. Tour., vol. 23, no. 7, pp. 1029-1048, 2015.

[21] I. Baumane-Vitolina, D. Dudek, N. Solarz, Y. Suh, G. Yildirimer, and Z. N. Tesfaye, "Human Capital and Social Capital as Important Components of Innovation Ecosystems and Economic Development," Humanit. Soc. Sci. - Latv., vol. 27, no. 1, pp. 93-119, 2019.

[22] H. Le Nguyen, "The Impacts of Tour Guide Performance on Foreign Tourist Satisfaction and Destination Loyalty in Vietnam," University of Western Sydney, 2015.

[23] B. Hurombo, “Assessing key tour guide competences to co-create memorable tourism experiences," North-West University, 2016.

[24] B. B. Boley and G. T. Green, "Ecotourism and natural resource conservation: The 'potential' for a sustainable symbiotic relationship," J. Ecotourism, vol. 15, no. 1, pp. 36-50, 2016.

[25] A. Duarte Alonso, "Exploring a developing tourism industry: A resource-based view approach," Tour. Recreat. Res., vol. 42, no. 1, pp. 45-58, 2017.
[27] E. B. Foa and U. G. Foa, "Resource theory: Interpersonal behaviour as exchange," in Social Exchange: Advances in Theory and Research, K. J. Gergen, M. S. Greenberg, and R. H. Willis, Eds. New York: Plenum, 1980.

[28] K. M. Eisenhardt and F. M. Santos, "KnowledgeBased View : A New Theory of Strategy?," in Handbook of Strategy and Management, A. Pettigrew, H. Thomas, and R. Whittington, Eds. Sage Publications, 2000.

[29] G. Becker, Human Capital: A Theoretical and Empirical Analysis with Special Reference to Education. Chicago: University of Chicago Press, 1964.

[30] P. He, Y. He, and F. Xu, "Evolutionary Analysis of Sustainable Tourism,” Ann. Tour. Res., March 2018.

[31] J. Baker, "Tourismification and Integration of Buganda's Culture in Community Socio-economic Activities for Poverty Reduction and Sustainable Development," J. Environ. Sci. Eng. A, vol. 6, pp. 98109, 2017.

[32] W. M. Ahebwa, J. P. Aporu, and J. B. Nyakaana, "Bridging community livelihoods and cultural conservation through tourism : Case study of Kabaka heritage trail in Uganda," Tour. Hosp. Res., vol. 16, no. 2, pp. 103-115, 2016.

[33] N. Duxbury and G. Richards, "Towards a research agenda for creative tourism: developments, diversity, and dynamics," in A Research Agenda for Creative Tourism, Edward Elgar Publishing, 2017, pp. 1-14.

[34] H. M. J. J. D. Snelders and E. G. Lea, "Different Kinds of Work, Different Kinds of Pay: An Examination of the Overjustification Effect," J. Socio. Econ., vol. 25, no. 4, pp. 517-535, 1996.

[35] A. Hjalager, "Suppliers as Key Collaborators for Sustainable Tourism Development," in Collaboration for Sustainable Tourism Development, 2018, p. 187.

[36] D. De Lange and R. Dodds, "Increasing sustainable tourism through social entrepreneurship," Int. J. Contemp. Hosp. Manag., vol. 29, no. 7, pp. 1977-2002, 2017.

[37] J. S. Lian, "A study of smart destination and its influence on innovation and sustainable development processes," Nord Universitet, 2018. 
[44] M. Y. Cetinkaya and Z. Oter, "Role of tour guides

[38] A. Budeanu, G. Miller, G. Moscardo, and C. Ooi, "Sustainable Tourism, Progress, Challenges and Opportunities: Introduction to this Special Volume," J. Clean. Prod., pp. 285-294, 2016.

[39] A. García-sánchez, D. Siles, and M. D. M. Vázquez-méndez, "Innovation, Competitiveness and Prosperity: A Factor Analysis of Innovation Indicators in Spain," Manag. Stud., vol. 6, no. 5, pp. 375-383, 2018.

[40] S. M. Isa, S. Kiumarsi, and M. A. Hamid, "Perceived Innovation Characteristics and Business Sustainable Orientation on Tour Operator Roles on Sustainable Tourism: Mediating for Sustainable Destination Management," in Proceedings of the Global Conference on Business, Hospitality, and Tourism Research : Volume 1, 2018, vol. 1, pp. 29-31.

[41] S. Salunke, J. Weerawardena, and J. R. MccollKennedy, "The central role of knowledge integration capability in service innovation-based competitive strategy," Ind. Mark. Manag., vol. 76, pp. 144-156, 2019.

[42] A. Nair, O. Guldiken, S. Fainshmidt, and A. Pezeshkan, "Innovation in India : A review of past research and future directions," Asia Pacific J. Manag., vol. 32, no. November, pp. 925-958, 2015.

[43] C. Díaz-garcía, Á. González-Moreno, and F. J. Sáez-martínez, "Eco-innovation : insights from a literature review," Innov. Manag. Policy Pract., vol. 17, no. 1, pp. 6-23, 2015. on tourist satisfaction level in guided tours and impact on re-visiting Intention : a research in Istanbul," Eur. J. Tour. Hosp. Recreat., vol. 7, no. 1, pp. 40-54, 2016.

[45] P. Kunasekaran, S. Ramachandran, and S. S. Gill, "Utilizing cultural and natural resources towards sustainability of indigenous tourism : A case study of Mah Meri community in Carey, Island, Malaysia," Options, vol. 20, no. 1, pp. 3-11, 2016.

[46] M. Hoskens, J. Delanote, K. Debackere, and L. Verheyden, "State of the art insights in capturing, measuring and reporting firm-level innovation indicators," in OECD Blue Sky Forum on Science and Innovation Indicators, 2016, no. August.

[47] M. Caber, G. Yilmaz, D. Kiliçarslan, and A. Öztürk, "The effects of tour guide performance and food involvement on food neophobia and local food consumption intention," Int. J. Contemp. Hosp. Manag., vol. 30, no. 3, pp. 1472-1491, 2018.

[48] J. Molina and X. Font, "Mixed methods in sustainable tourism : an analysis of prevalence, designs and application in JOST (2005 to 2014), ” J. Sustain. Tour., vol. 24, no. 4, pp. 549-573, 2016.

[49] A. Arnaud, "Conceptualizing and Measuring Ethical Work Climate: Development and Validation of the Ethical Climate Index (ECI).," Acad. Manag. Annu. Meet. Proc., vol. 8, no. 1, pp. E1-E6, 2006. 